\title{
Evaluations on The Landscapes of School Gardens: İzmit Central District of Kocaeli Province Sample
}

\author{
Aysun ÇELIK ${ }^{1 *}$, Elvan ENDER ${ }^{2}$
}

\section{Öz}

Okul bahçeleri; rekreasyonel, sosyal, ekolojik, psikolojik, öneme sahip olup, çocuk ve gençlerin yetişmesini, gelişmesini etkileyen alanlardır. Çocuk ve gençlerin günlük yaşamlarının büyük bir bölümü de okulda ve okul bahçelerinde geçtiğinden, okul bahçelerinin düzenlenmesi iç mekanlar kadar önemli alanlardır.

Bu çalışmanın amacı; Kocaeli ili İzmit merkez ilçesinde bulunan okullar örneğinde, okul bahçelerinin peyzajına ilişkin durum değerlendirmesi yapmaktır. Bu amaçla; İzmit’te yer alan 30 ilköğretim okulu ve 19 lise-dlengi okul olmak üzere toplam 49 adet okul bahçesi, alan kullanım biçimleri, donatı elemanları ve bitki materyali yönünden incelenerek değerlendirmeler yapılmıştir. Okulların alan kullanımlarına ilişkin analizlerde oransal dağııım, donatı elemanları ve bitki materyali verilerinin analizinde ise frekans dağıımı yöntemleri kullanılmıştır. Çalışmadan elde edilen sonuçlara göre; okul bahçelerinin peyzajına yeteri kadar önem verilmediği belirlenmiştir. Alan kullanımı yönünden mevcut değerlerin, gelismis ülkelerdeki standartların çok altında olduğu tespit edilmiş, ilköğretim okullarının sadece $\% 43,33$ 'ünde, lise ve dengi okullarında ise \%57,89'unda yeşil alanların bulunduğu tespit edilmiștir. Yeşil alan varlığı yöınünden; en fazla yeşil alana sahip olan okul ile en az yeşil alana sahip olan okul arasında ilköğretim okullarında 313 kat fark, lise ve dengi okullarda ise 57 kat fark olduğu belirlenmiştir. Mevcut yesil alanlarda ise bitki tür çeşitliliği çok. azdır. Çim alanlar ile çiçeklikler yok denecek düzeydedir. Oyun çağındaki çocukların eğitim gördüğü ilköğretim okullarının \%93,34'ünde oyun grubu bulunmamaktadır. Lise ve dengi okulların \%47'sinde basketbol ve voleybol için uygun çok amaçlı spor alanı bulunmaktadır.

Çalışma sonucunda, okul bahçelerinin eğitim ve öğretimin bir parçası olarak ele alınması gerektiği, tüm öğrencilerin eğitim ve öğretim imkanlarından eşit olarak yararlanabilmesi için donatı alanları ve donatı elemanları organizasyonunda eşitcil bir standartın getirilmesi önerilmektedir.

Anahtar Kelimeler: Izmit, Okul Bahçesi, Peyzaj, Peyzaj Elemanları, Alan Kullanımı

\section{Okul Bahçelerinin Peyzajına İlişkin Durum Değerlendirmesi: Kocaeli ili İzmit Merkez İlçesi Örneği}

\begin{abstract}
School gardens are the spaces that affect the growth and development of children and the teenagers with their recreational, social, ecological and psychological importance. Since the children and the teenagiers spend the majority of their daily lives at schools and in school gardens, the design of these gardens is as important as the indoor designs. The objective of this study is to evaluate the current status of the landscape of the school gardens considering the sample schools located in İmit, central district of Kocaeli province. For this purpose, a total of 49 school gardens, 30 of which belong to primary schools and 19 to high schools and their equivalents, have been studied and evaluated in terms of space use profiles, landscape design components and vegetal components. While proportional range method has been used in the analysis of the space use at schools, frequency analysis method has been utilised in the analysis of the data relating the landscape components and the vegetal components. According to the results derived from the study it has been determined that landscape design of the school gardens is ignored. It has also been determined that the rates related to space use are far below the standards when compared with the developed countries. Green space use has been observed only in $43.33 \%$ of the primary schools and $57.89 \%$ of high schools and their equivalents. When considered in terms of green space use, it has been specified that the difference between the school with the largest green area and the school with the least green area is 313 times higher in primary schools and 57 times higher in high schools and their equivalents. Plant diversity, on the other hand, on existing green spaces has been determined to be quite poor. Grass areas and flower beds are scarcely used. $93.34 \%$ of the primary schools, where children at play age are trained, do not have playgroups. Similarly, $47 \%$ of the high schools and their equivalents do not have multifunctional playgrounds suitable for basketball and volleyball games.

As a result of the study, it has been suggested that the school gardens should be regarded as a part of education and training; a uniform standard should be adopted in the organisation of spaces and components in order to ensure that all students have equal access to education and training opportunities.
\end{abstract}

Keywords: Izmit, Landscape Design, Landscape Design Elements, School Garden, Space Use

\footnotetext{
${ }^{1}$ Uludağ University, Faculty of Agriculture, Department of Landscape Architecture BURSA-TÜRKIYE, celikaysun06@yahoo.com.tr

${ }^{2}$ Uludağ University, Faculty of Agriculture, Department of Landscape Architecture BURSA-TÜRKIYE, *ilgili yazar / Corresponding author: Aysun ÇELIK , aysuncelik@uludag.edu.tr

Gönderim Tarihi: 26.12.2016
}

Kabul Tarihi: 02.05.2017 


\section{INTRODUCTION}

Schools constitute the most influential environment where a child spends most of his/her time. Data derived and incidences observed through this environment form the keystones for the adaptation of the child to the society as a healthy individual (Erdönmez, 2007). School gardens, on the other hand, are open spaces which are to be designed and equipped for enabling children and teenagers carry out recreational activities, sports activities and entertainment.

School gardens should meet recreational needs of the students and form an attractive and comfortable environment where the students shall feel themselves relaxed in their spare times (Golby and Appleby, 1997).

An important aspect of the school gardens and their planning especially due to increasing environmental problems is their ability to train individuals who are sensitive to the environment and, at the same time, who can protect nature and its units (Bradley, 1995). Many of the urban spaces are surrounded by concrete and asphalt as a result of unplanned urbanization. Children and teenagers live away from nature and natural environment. Therefore, as an effective means of learning, green space is of great importance. School gardens are also good opportunities for understanding children and young people. Encouraging group works in these gardens shall promote cooperation among students as well.

As a result of insufficient space and limited resources that hinder students from moving freely in most of the school gardens, not all the students are able to benefit from the opportunities equally. Playgrounds included within the borders of school gardens, enable children to be mentally dynamic during break times throughout the day. Another factor providing particularly healthy life environments within the outdoor layout of the school gardens is the presence of vegetal components and their aesthetical design (Aksu and Demirel 2011).

According to Çorlu (1996), the influence of the school gardens on the students are evaluated considering following titles:

$\checkmark$ Physical and mental development

$\checkmark$ Recreation

$\checkmark$ The creation of activities that respond to most of the students' needs

$\checkmark$ Ensuring security of life and property of the students

$\checkmark$ Rising awareness of the environment and interacting with the environment

$\checkmark$ Student socialization

$\checkmark$ Providing hygienic environment for students

$\checkmark$ Utilisation of the garden as a place of education and training.

An ideal school garden should include a kind of natural landscape space. The use of indoor, outdoor and green spaces should be planned considering grade and age differences. The following places should be taken into consideration during planning of the mentioned spaces: Playfields, spaces set for vegetation, sitting components, potable water facilities and water fountains, hiking trails, parking and bicycle lots, shuttle parks, personnel and guard booths, parade areas and multifunctional spaces, waiting areas for parents and meeting halls for the use of parent-teacher association. Besides, design components such as terrarium, vivarium, aquarium, and plant pool for ecological applications should exist (Wolf 1967). Besides, school gardens should include vegetal components (trees, bushes, flowers and grass areas); animals; ponds or pools; sites and components suitable for sitting, leaning, taking shelter or hiding; some kind of flexible equipment and areas that encourage the children to create their own space by using their own imagination and creativity (Fjortoft and Sageie 2000). 
The Ministry of National Education of the Republic of Turkey involves the following principles regarding the designing of the school gardens:

In terms of space use, besides educational structures and students' hostels at boarding schools, schools should have amphitheatres and suitable areas for outdoor classes to handle the lectures in the open air under appropriate air conditions. Thereby, students shall find opportunities to express themselves; improve their creativity and imagination; a kind of stimulation shall be provided for their curiosity and they will be able to present their educational and cultural activities on these spaces. School gardens should include at least one volleyball court and one basketball court. The dimensions of the volleyball court should be $13 \mathrm{~m} \times 22 \mathrm{~m}$ and the basketball court should be $19 \mathrm{~m} \times 32 \mathrm{~m}$. On the conditions that the school garden has enough space, it is advised to have an indoor sports hall and a miniature football pitch with the dimensions $24 \mathrm{~m} \times 42 \mathrm{~m}$. In order to ensure the creation and continuity of common local and cultural values among students, playgrounds for traditional children games should also be included within the borders of school gardens. For instance the dimensions of the playground for the game "9 Men's Morris", which is one of the traditional children games, should be either $3 \mathrm{~m} \mathrm{x}$ $3 \mathrm{~m}, 2 \mathrm{~m} \times 2 \mathrm{~m}$ or $1 \mathrm{~m} \times 1 \mathrm{~m}$. As for the playground of the game "Drop the Handkerchief", another traditional game, the dimensions should be minimum $15 \mathrm{~m} \times 27$ $\mathrm{m}$ or maximum $20 \mathrm{~m} \times 40 \mathrm{~m}$. The playground for "Hopscotch", on the other hand, should consist of 8 squares with the dimensions $45 \mathrm{~cm} \times 45 \mathrm{~cm}$ each. The floor of the playgrounds should be smooth and flat. Furthermore school gardens should have parade areas ground of which should be covered with anti-slide material providing a space of at least $2 \mathrm{~m}^{2}$ for each student. As for design components, the Ministry makes it obligatory that every school garden has a space for Ataturk's Bust and a minimum 6 $\mathrm{m}$-tall flag post on the right hand side of the school garden when entered. Additionally, areas that contribute children's physical development with the activities such as running, jumping, climbing and appropriate game tools and equipment for the age groups should be included. Arbour-shaped sitting areas and sitting groups, made of wooden material preferably, that enable students and teachers to sit; have some rest and communicate when not handling the classes and thus contribute to their social development should also be included. School gardens should also include as much as possible green areas; ecologically compatible plants; flower parterres which are designed around some principles and are easy to maintain. Thus, the cold and monotonous effect of hard floors should be broken. There should be walking paths linking functional areas within the school garden and providing walking opportunities in the fresh air (http://www.meb.gov.tr).

Moreover, school gardens in Turkey are not deemed to be sufficient by the users and school administrations in terms of landscape characteristics. These spaces do not bear features that enable students enhance their physical activities. Unfortunately, involving natural landscape elements such as plants, water and soil in outdoor spaces of the schools is at minimum level. Parents and school administrations demand landscape features be enhanced (Özdemir and Yılmaz 2009).

The objective of this study is evaluating the landscape status of the school gardens located in İmit, central district of Kocaeli province, and specifying the sufficiency and the deficiencies in practise. The absence or inadequacy of standard criteria for the landscaping of school gardens in Turkey has been a limiting factor in the study. The evaluations have been carried out in line with the principles of school garden designing regulations of the Ministry of National Education and the criterion of $25 \mathrm{~m}^{2}$ minimum garden area per student (Akdoğan,1972), which is applied in many countries.

\section{MATERIALS and METHODS}

\subsection{Materials}


The study was carried out among 30 primary schools and 19 high schools and their equivalents located in İzmit, the central district of Kocaeli Province, between the years 2013-2014. Kocaeli Province is located in the Marmara Region and surrounded with Black Sea in the north; Bursa in the south; İstanbul in the west and northwest; Sakarya in the east (Figure 1). The Province consists of 12 districts including central district İzmit. The central district, İzmit, is a coastal settlement near the eastern end of İzmit Bay. Data, visuals and observations derived through field studies carried out at schools which are located in the İzmit district; documents obtained from the administrations of each school and Kocaeli Provincial Directorate of National Education and previous researches that had been carried out on the subject matter form the main material of the study.

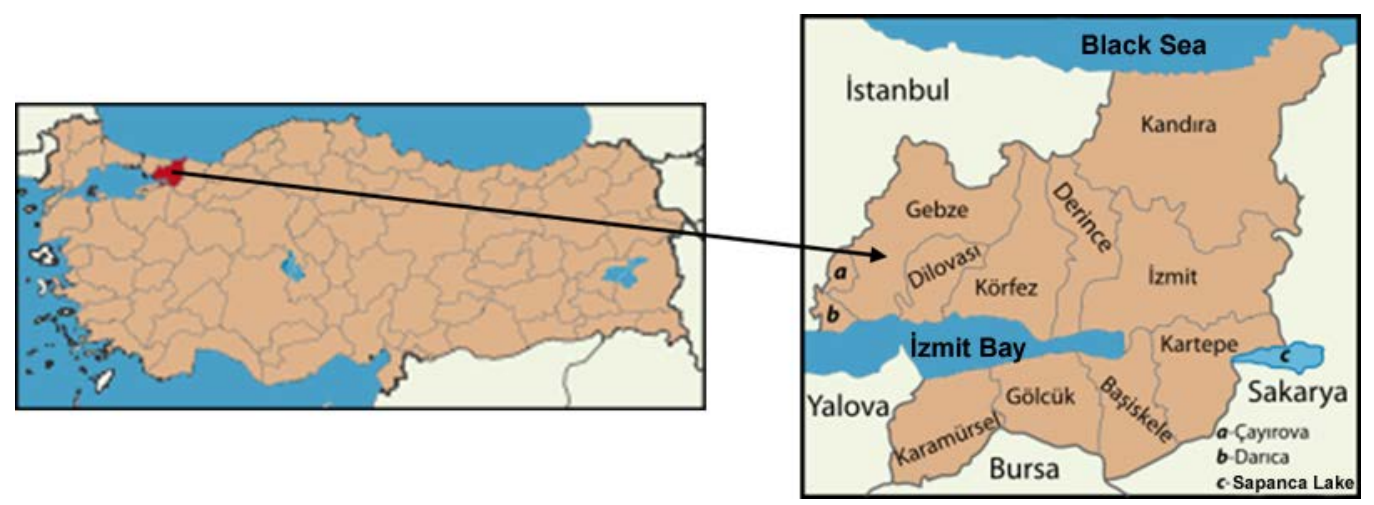

Figure 1. Geographical location of Kocaeli

There are 142 schools located in İzmit, the central district of Kocaeli province. 9 of these schools are nursery schools, 51 are primary schools, 43 are secondary, 20 of them are high schools and 10 are vocational training centres. All the primary schools and high schools with their equivalents in İmit have been covered within this study. However schools with insufficient data have been excluded. Therefore, $59 \%$ of the primary schools and $95 \%$ of the high schools and their equivalents have been included within the study. Figure 2 and 3 indicate the locations of Primary and High Schools and Their Equivalents respectively included in the study.

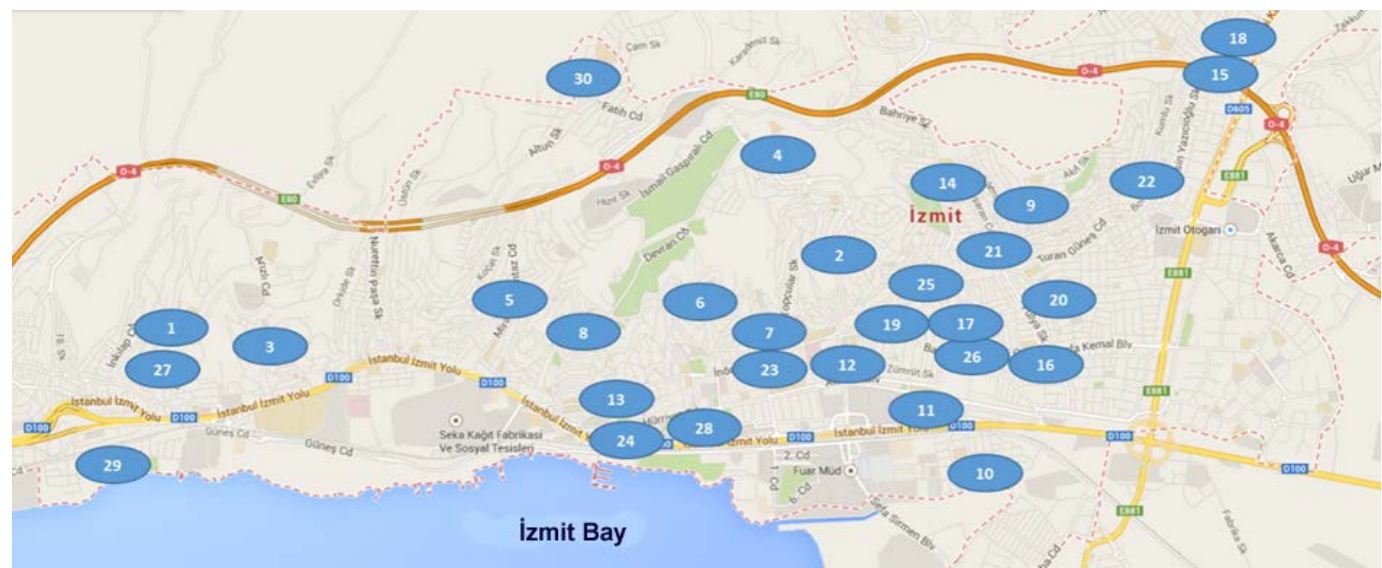

1. Zafer Primary School (P.S), 2.Topçular P.S, 3. Yenimahalle P.S, 4. Muammer Aksoy P.S, 5. İnkılap P.S, 6. Akşemsettin P.S, 7. Mehmet Akif P.S, 8. Ertuğrul Gazi P.S, 9. İbrahim Süreyye Yiğit P.S, 10. Türk Pireli P.S, 11. Atatürk P.S, 12. 28 Haziran P.S, 13. Akçakoca P.S, 14. Ulubatlı Hasan P.S, 15. Yarb. Refik Cesur P.S, 16. Albay İbrahim Karaoğlanoğlu P.S, 17. Kazım Karabekir P.S, 18. Dr. Ferdi Koçal P.S, 19. Fevzi Çakmak P.S, 20. Mimar Sinan P.S, 21. Leyla Atakan P.S, 22. Tavşantepe P.S, 23. Saraybahçe P.S, 24. 50.Yıl Cumhuriyet P.S, 25. Bekirpaşa Vakıf P.S, 26. İbni Sina P.S, 27. Mehmetçik P.S, 28. Ulugazi P.S, 29. 75.Yıl Cumhuriyet P.S, 30. Özel Atafen P.S

Figure 2. Location of Primary School 


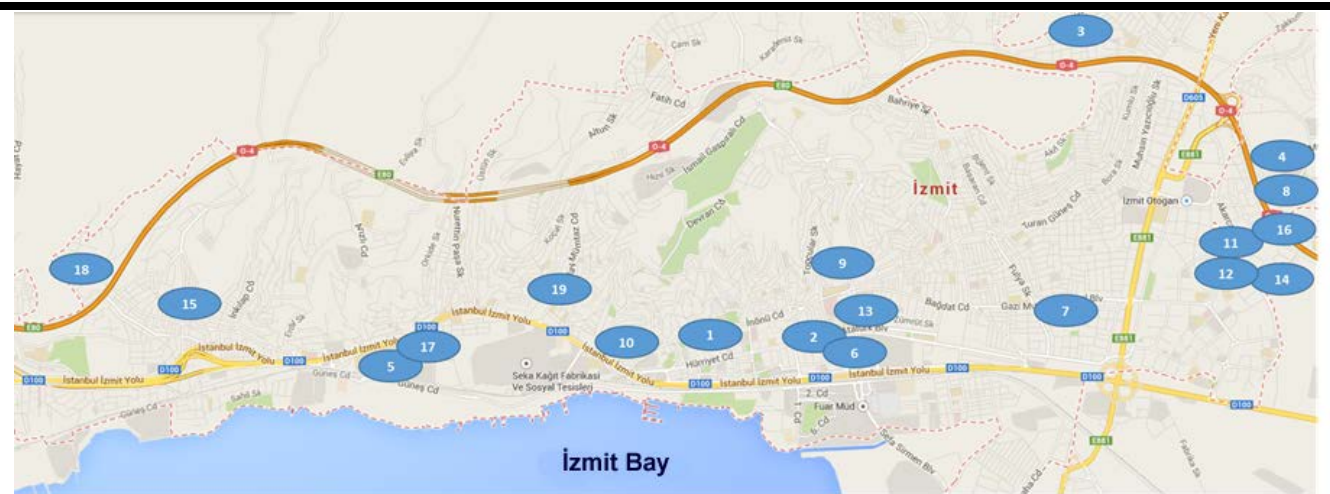

1.Izmit High School (H.S)., 2. Vocational H.S , 3. İzmit Mualllim Naci H.S., 4. Ataturk Technical and Vocational H.S., 5. Cahit Elginkan H.S., 6. Kocaeli Medical Vocational H.S, 7. Namık Kemal H.S., 8. Sabancı Technical and Vocational H.S., 9. Mimar Sinan H.S., 10. İzmit Girls' Vocational High School, 11. 24 Kasım H.S., 12. İzmit Trade Vocational H. S., 13. İzmit Atılım H.S., 14. Yahya Kaptan H.S., 15. Kocaeli Tourism Vocational H.S., 16. İzmit Başöğretmen H.S., 17. Muammer Dereli Teacher Training H.S., 18. Özel Marmara 2000 H.S., 19. İnkılap H.S.

Figure 3. Location of High Schools and Their Equivalents

\subsection{Methods}

In order to obtain space data, primarily, a space data form has been created. Observation, research and scoring data from picked schools and the original data from school administration interviews has been recorded in the form. Space data include space use information from schools and information related to vegetal and landscape design reinforcement components. The data concerning the space size of the schools have been derived from Kocaeli Provincial Education Directorate and the data related to the number of registered students from school administrations. The space use profile, the type and number of landscape design components and the type of vegetal use have been acquired through on-site observations, researches and inventory under consent of the school administrations. While specifying the type of the samples taken from existing plants in green spaces of the schools, the following sources has been used: Davis, 1965-1988; Krussmann, 1984-1986; Yaltırık, 1988; Pamay, 1992; Pamay 1993; Brand 1997-2001; Mataracı 2002; Evans, 2005; Mamıkoğlu, 2007”. While analysing space use of the schools, rational range method has been utilized. On the other hand, the data related to vegetal and landscape design reinforcement components have been analysed through frequency distribution method.

\section{RESEARCH FINDINGS}

\subsection{Findings relating space use}

Total education period in primary schools is 8 years and compulsory primary education includes pupils between the ages 6-14. Table 1 indicates the space use and amount of space per student in primary schools included within this study.

Table 1. Space use and amount of space per student in primary schools

\begin{tabular}{|c|c|c|c|c|c|c|c|c|c|}
\hline $\begin{array}{l}\text { Name of the } \\
\text { Primary School }\end{array}$ & 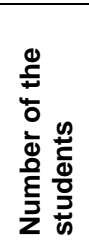 & 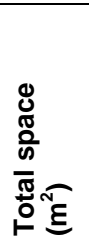 & 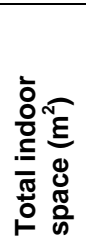 & 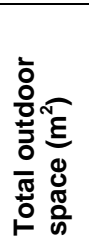 & 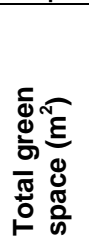 & 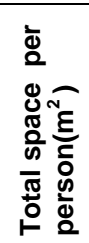 & 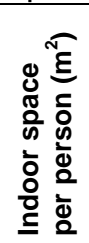 & 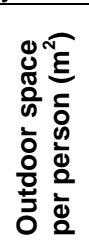 & 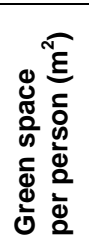 \\
\hline $\begin{array}{l}\text { Zafer P.S } \\
\text { Topçular P.S } \\
\text { Yenimah P. }\end{array}$ & $\begin{array}{l}663 \\
655 \\
400\end{array}$ & $\begin{array}{l}3324 \\
4750 \\
6450\end{array}$ & $\begin{array}{l}1200 \\
750 \\
1450\end{array}$ & $\begin{array}{l}2124 \\
4000 \\
5000\end{array}$ & $\begin{array}{l}50 \\
200 \\
2500\end{array}$ & $\begin{array}{l}5.01 \\
7.25 \\
16.12\end{array}$ & $\begin{array}{l}1.81 \\
1.14 \\
3.62\end{array}$ & $\begin{array}{l}3.20 \\
6.11 \\
125\end{array}$ & $\begin{array}{l}0.07 \\
0.30 \\
6.25^{* *}\end{array}$ \\
\hline
\end{tabular}


Evaluations on The Landscapes of School Gardens: İzmit Central District of Kocaeli Province Sample

\begin{tabular}{|c|c|c|c|c|c|c|c|c|c|}
\hline $\begin{array}{l}\text { Muammer Aksoy } \\
\text { P.S }\end{array}$ & 350 & 3000 & 1200 & 1800 & - & 8.57 & 3.43 & 5.14 & - \\
\hline İnkılap P.S & 1000 & 4414 & 1024 & 3390 & 800 & 4.41 & 1.02 & 3.39 & 0.8 \\
\hline Akşemsettin P.S & 420 & 940 & 200 & 740 & - & 2.24 & 0.48 & 1.76 & - \\
\hline Mehmet Akif P.S & 672 & 2544 & 650 & 1894 & 86 & 3.79 & 0.97 & 2.82 & 0.12 \\
\hline $\begin{array}{l}\text { Ertuğrul Gazi } \\
\text { P.S }\end{array}$ & 310 & 500 & 350 & 150 & - & 1.61 & 1.12 & $0.48^{*}$ & - \\
\hline $\begin{array}{l}\text { İbrahim Sür. } \\
\text { Yiğit İO }\end{array}$ & 496 & 8000 & 750 & 7250 & 500 & 16.13 & 1.51 & 14.62 & 1.01 \\
\hline Türk Pireli P.S & 750 & 10000 & 6000 & 4000 & 2000 & 13.33 & 0.8 & 5.33 & 2.66 \\
\hline Atatürk P.S & 436 & 2452 & 1650 & 802 & 70 & 5.62 & 3.78 & 1.83 & 0.16 \\
\hline 28 Haziran P.S & 1062 & 7000 & 4000 & 3000 & - & 6.59 & 3.76 & 2.82 & - \\
\hline Akçakoca P.S & 204 & 1760 & 1000 & 760 & - & 8.63 & 4.90 ** & 3.72 & - \\
\hline $\begin{array}{l}\text { Ulubatlı Hasan } \\
\text { P.S }\end{array}$ & 435 & 7500 & 1000 & 6500 & 500 & 17.24 & 2.30 & 14.94 & 1.14 \\
\hline $\begin{array}{l}\text { Yarbay Refik } \\
\text { Cesur P.S }\end{array}$ & 1059 & 6529 & 829 & 5700 & 50 & 6.16 & 0.78 & 5.38 & 0.04 \\
\hline $\begin{array}{l}\text { Albay İbrahim } \\
\text { Kara. P.S }\end{array}$ & 717 & 5050 & 1250 & 3800 & - & 7.04 & 1.74 & 5.30 & - \\
\hline $\begin{array}{l}\text { Kazım Karabekir } \\
\text { P.S }\end{array}$ & 1031 & 6960 & 1400 & 2160 & 20 & 6.75 & 1.36 & 2.09 & $0.02^{*}$ \\
\hline $\begin{array}{l}\text { Dr. Ferdi Koçal } \\
\text { P.S }\end{array}$ & 596 & 2500 & 900 & 1600 & 600 & 4.19 & 1.51 & 2.68 & 1.0 \\
\hline $\begin{array}{l}\text { Fevzi Çakmak } \\
\text { P.S }\end{array}$ & 776 & 2600 & 1200 & 1400 & - & 3.35 & 1.55 & 1.55 & - \\
\hline Mimar Sinan P.S & 2115 & 4412 & 722 & 3690 & - & 2.08 & $0.34^{*}$ & 1.74 & - \\
\hline $\begin{array}{l}\text { Leyla Atakan } \\
\text { P.S }\end{array}$ & 1315 & 4000 & 1000 & 3000 & - & 3.04 & 0.76 & 2.28 & - \\
\hline Tavşantepe P.S & 1318 & 4300 & 550 & 3750 & - & 3.26 & 0.42 & 2.84 & - \\
\hline Saraybahçe P.S & 327 & 3405 & 643 & 2762 & - & 10.41 & 1.96 & 8.44 & - \\
\hline $\begin{array}{l}50 . \text { YII } \\
\text { Cumhuriyet P.S }\end{array}$ & 1544 & 1962 & 1722 & 240 & - & $1.27^{*}$ & 1.11 & 0.15 & - \\
\hline $\begin{array}{l}\text { Bekirpaşa Vakıf } \\
\text { P.S }\end{array}$ & 568 & 4875 & 650 & 4225 & - & 8.58 & 1.14 & 7.44 & - \\
\hline İbni Sina P.S & 400 & 3500 & 1570 & 1930 & - & 8.75 & 3.92 & 4.82 & - \\
\hline Mehmetçik P.S & 652 & 2600 & 1300 & 1300 & - & 3.99 & 1.99 & 1.99 & - \\
\hline Ulugazi P.S & 2065 & 3621 & 1821 & 1800 & - & 1.75 & 0.88 & 0.87 & - \\
\hline $\begin{array}{l}\text { 75.YII } \\
\text { Cumhuriyet P.S }\end{array}$ & 226 & 3300 & 300 & 3000 & 1000 & 14.60 & 1.33 & 13.27 & 4.42 \\
\hline Özel Atafen P.S & 765 & 30,000 & 3000 & 27000 & - & $\begin{array}{l}39.22^{*} \\
*\end{array}$ & 3.92 & $\begin{array}{l}35.29 * \\
*\end{array}$ & - \\
\hline TOTAL & 23.327 & 152.248 & 40.081 & 108.767 & 8376 & 223.24 & 55.35 & 174.79 & 17.99 \\
\hline
\end{tabular}

As indicated in Table 1, total number of registered students in the 30 primary schools in 2013 located in İzmit, the central district of Kocaeli Province, is 23327. The total indoor and outdoor space of the schools is $152248 \mathrm{~m}^{2}$, whereas total indoor space sum

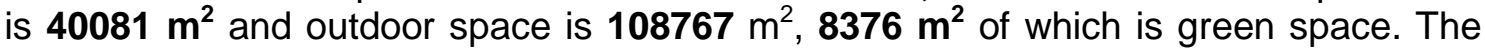
maximum amount of space per student for total indoor spaces is $39.22 \mathrm{~m}^{2}$ whereas for outdoor spaces it is $35.29 \mathrm{~m}^{2}$ and $6.25 \mathrm{~m}^{2}$ for green spaces.

Figure 4 indicates the maximum and minimum rates of spaces per person. Accordingly, when schools are compared in terms of outdoor space, the maximum outdoor space rate is nearly 74 times bigger than the minimum rate. When the schools are compared in terms of green space presence, this difference becomes nearly 313 times. 


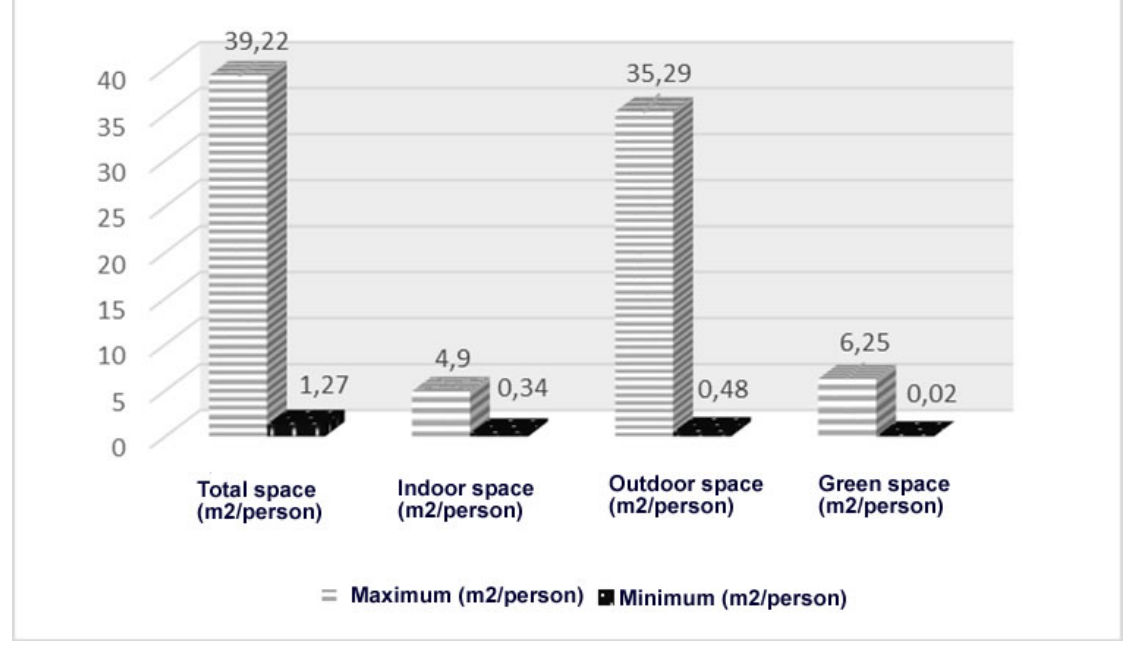

Figure 4. Maximum and minimum rates of space per person (Primary Schools)

High schools and their equivalents cover teenagers. Similarly, for an efficient learning environment, environmental factors need to be well organised.

Table 2 indicates space use data of 19 high schools and their equivalents located in İzmit, central district of Kocaeli Province.

Table 2. Space use and amount of space per student in high schools and their equivalents

\begin{tabular}{|c|c|c|c|c|c|c|c|c|c|}
\hline \multicolumn{10}{|l|}{ Name of the School } \\
\hline & 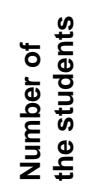 & 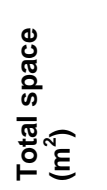 & 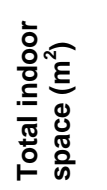 & 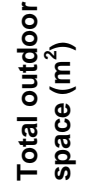 & 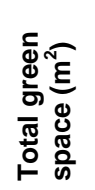 & 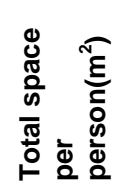 & 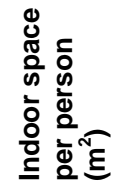 & 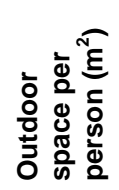 & 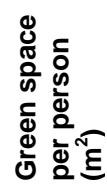 \\
\hline İzmit H.S. & 650 & 7123 & 1000 & 6123 & 1000 & 10.96 & 1.54 & 9.42 & 1.54 \\
\hline Endüstri Meslek H.S & 3187 & 35435 & 9928 & 25507 & 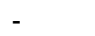 & 11.12 & 3.12 & 8.00 & - \\
\hline İzmit Mualllim Naci H.S & 332 & 7000 & 1000 & 6000 & 1000 & 21.08 & 3.01 & 18.07 & - \\
\hline Ataturk Tech. and Voc. H.S & 1506 & 55000 & 42000 & 13000 & 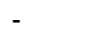 & 36.52 & 27.89 & 8.63 & - \\
\hline Cahit ElginkanAnadolu H.S. & 763 & 16500 & 8100 & 8400 & 1200 & 21.63 & 10.62 & 11.00 & 1.57 \\
\hline Kocaeli Medical Voc. H.S & 420 & 3400 & 640 & 2760 & 2000 & 8.09 & $1.52^{*}$ & 6.57 & 4.76 \\
\hline Namık Kemal H.S. & 615 & 7132 & 1500 & 5632 & - & 11.60 & 2.44 & 9.16 & - \\
\hline Mimar Sinan H.S. & 826 & 6445 & 1728 & 4717 & - & 7.80 & 2.09 & 5.71 & - \\
\hline İzmit Girls' Vocational H.S. & 1400 & 15000 & 13500 & 1500 & - & 8.42 & 9.64 & 1.07 & 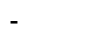 \\
\hline Sabancı Tech. and Voc. H.S & 549 & 15000 & 5000 & 10000 & 1000 & 27.32 & 9.11 & 18.21 & 1.82 \\
\hline 24 Kasım H.S. & 570 & 7719 & 2719 & 5000 & 3000 & 13.54 & 4.77 & 8.77 & 5.26 \\
\hline İzmit Trade Vocational H.S & 1050 & 10383 & 2256 & 8127 & - & 9.89 & 2.15 & 7.74 & - \\
\hline Inkılap H.S. & 393 & 3337 & 1000 & 2337 & 300 & 8.49 & 2.54 & 5.95 & 0.76 \\
\hline İzmit Atılım H.S. & 700 & 11500 & 6500 & 5000 & 4500 & 16.43 & 9.28 & 7.14 & 6.42 \\
\hline Yahya Kaptan H.S. & 850 & 15300 & 8349 & 6951 & 836 & 18.00 & 9.82 & 8.18 & 0.98 \\
\hline Kocaeli Tourism Voc. H.S & 217 & 920 & 735 & 185 & 30 & 4.24 & 3.39 & $0.85^{*}$ & $0.14^{*}$ \\
\hline İzmit Başöğretmen H.S. & 278 & 860 & 530 & 330 & 150 & $3.09 *$ & 1.90 & 1.19 & 0.54 \\
\hline $\begin{array}{l}\text { Muammer Dereli Teach..T. } \\
\text { H.S }\end{array}$ & 456 & 26000 & 15500 & 10500 & 20 & $57.01^{\star *}$ & $33.99^{\star \star}$ & $23.02^{\star \star}$ & - \\
\hline Özel Marmara 2000 H.S. & 250 & 12000 & 8000 & 4000 & 2000 & 48.00 & 32.00 & 16.00 & 8.00 ** \\
\hline TOTAL & 15012 & 249002 & 129985 & 126069 & 17016 & 343.23 & 170.82 & 174.68 & 31.79 \\
\hline
\end{tabular}

As Table 2 indicates, total registered student number of 19 high schools and their equivalents in 2013 is $\mathbf{1 5 0 1 2}$. The total indoor and outdoor space of the schools is $249002 \mathrm{~m}^{2}$; whereas total indoor space sum is $129985 \mathrm{~m}^{2}$ and outdoor space is $126069 \mathrm{~m}^{2}, 17016 \mathrm{~m}^{2}$ of which is green space. The maximum amount of space per student ( $\mathrm{m}^{2} /$ student) for total spaces is $57.01 \mathrm{~m}^{2}$ whereas for indoor spaces it is 33.99 $\mathrm{m}^{2}, 23.02 \mathrm{~m}^{2}$ for outdoor spaces and $8.00 \mathrm{~m}^{2}$ for green spaces. 
When schools are compared in terms of outdoor space, the maximum outdoor space rate is nearly 27 times bigger than the minimum rate. When the schools are compared in terms of green space presence, this difference becomes nearly 57 times (Figure 5).

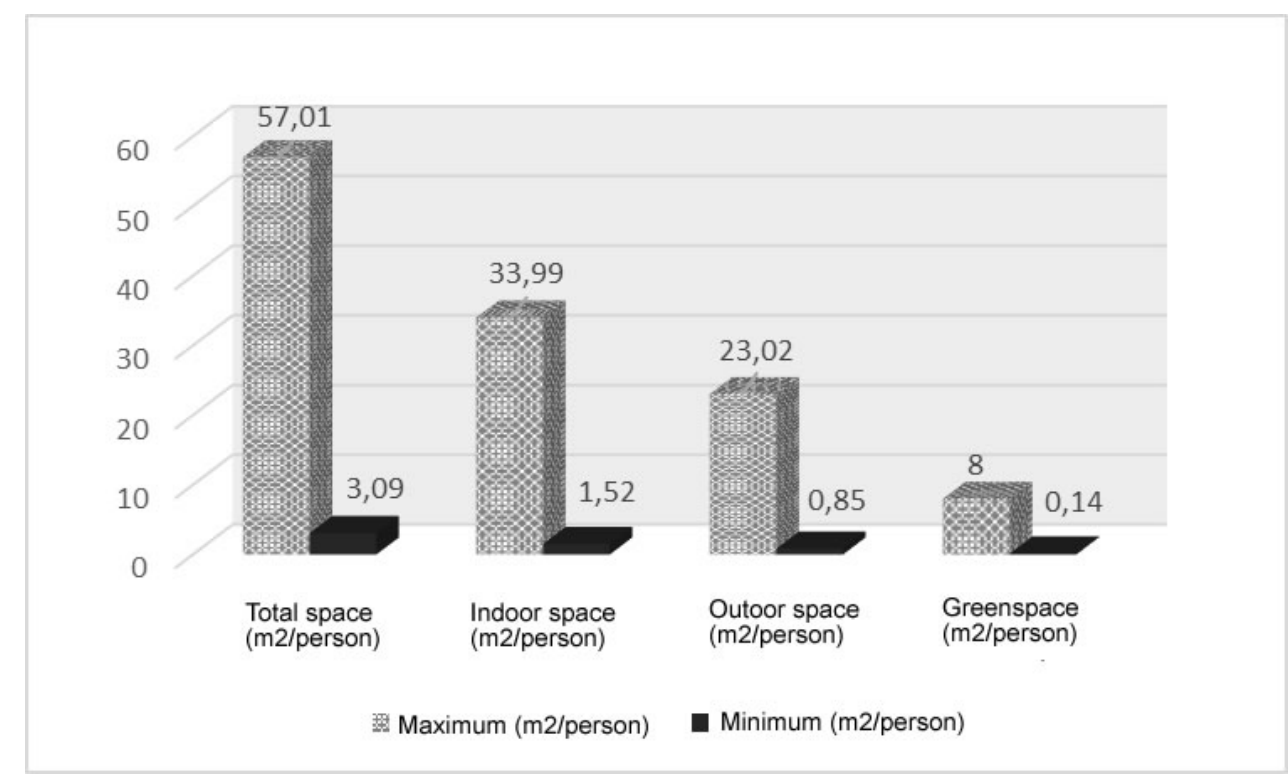

Figure 5. Maximum and minimum rates of space per person (High Schools and their equivalents)

\subsection{Findings related to landscape reinforcement components}

School gardens should have areas and components that enable students to perform activities such as running; climbing; jumping; walking; playing with water, sand and soil. The current status of primary schools in terms of reinforcement elements are presented in Table 3. The following formula has been used in determining the use rates of the reinforcement components:

Components use rate for schools $(\%)=\frac{\text { Total number of components in each school x } 100}{\text { Total number of components in all schools }}$

Table 3. Reinforcement element diversity and use rates in primary schools

\begin{tabular}{|c|c|c|c|c|c|c|c|c|c|c|c|c|c|c|c|c|c|c|}
\hline $\begin{array}{l}\text { Name of } \\
\text { the school }\end{array}$ & 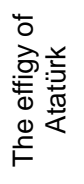 & $\begin{array}{l}\frac{0}{0} \\
\frac{0}{0} \\
\frac{\pi}{4}\end{array}$ &  & 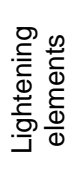 & 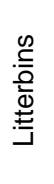 & $\cdot \frac{D}{\sum_{n}^{c}}$ & $\frac{\frac{0}{0}}{\omega}$ & $\begin{array}{l}0 \\
\frac{0}{7} \\
\frac{0}{5} \\
\frac{\pi}{\alpha}\end{array}$ & $\begin{array}{l}\frac{\mathscr{U}}{0} \\
\frac{\sigma}{ \pm} \\
\frac{0}{\frac{0}{0}} \\
\frac{0}{\alpha}\end{array}$ & 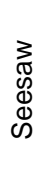 & $\begin{array}{l}\overline{\bar{z}} \\
\frac{0}{3}\end{array}$ & 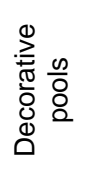 & 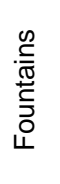 & 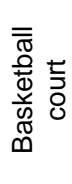 & 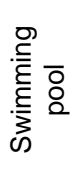 & 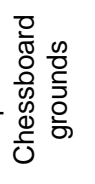 & $\begin{array}{l}\bar{\pi} \\
0\end{array}$ & 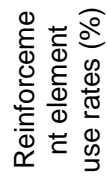 \\
\hline Zafer P.S & 1 & 2 & 6 & 2 & 8 & - & - & - & - & - & - & - & 1 & - & - & - & 20 & 3.19 \\
\hline $\begin{array}{l}\text { Topçular } \\
\text { P.S }\end{array}$ & 1 & 2 & 4 & 5 & 7 & - & - & - & - & - & 1 & - & 3 & - & - & - & 23 & 3.67 \\
\hline $\begin{array}{l}\text { Yenimah } \\
\text { P.S }\end{array}$ & 1 & 1 & - & 3 & 12 & - & - & - & - & - & - & - & 1 & - & - & - & 18 & 2.87 \\
\hline $\begin{array}{l}\text { Muammer } \\
\text { Aksoy P.S }\end{array}$ & 1 & 2 & 5 & 8 & 2 & - & - & - & - & - & - & - & - & - & - & - & 18 & 2.87 \\
\hline İnkılap P.S & 1 & 3 & 6 & - & 4 & - & - & - & - & - & - & - & - & - & - & - & 14 & 2.23 \\
\hline $\begin{array}{l}\text { Akşemsetti } \\
\text { n P.S }\end{array}$ & - & 1 & - & - & 2 & - & - & - & - & - & - & - & 3 & - & - & - & 6 & 0.96 \\
\hline $\begin{array}{l}\text { Mehmet } \\
\text { Akif P.S }\end{array}$ & 1 & 1 & 10 & 3 & 5 & - & - & - & - & - & - & - & - & - & - & - & 20 & 3.19 \\
\hline $\begin{array}{l}\text { Ert. Gazi } \\
\text { P.S } \\
\text { İbrahim }\end{array}$ & 1 & 1 & - & - & 2 & - & - & - & - & - & - & - & - & - & - & - & $\begin{array}{l}4 \\
4\end{array}$ & $0.64^{*}$ \\
\hline $\begin{array}{l}\text { Sür. Yiğit } \\
\text { PS }\end{array}$ & 1 & 1 & - & - & 2 & - & - & - & - & - & - & - & - & - & - & - & & $0.64^{*}$ \\
\hline
\end{tabular}




\begin{tabular}{|c|c|c|c|c|c|c|c|c|c|c|c|c|c|c|c|c|c|c|}
\hline $\begin{array}{l}\text { Türk Pireli } \\
\text { P.S }\end{array}$ & 1 & 1 & 10 & - & 15 & 1 & 1 & - & - & - & 1 & - & - & - & - & - & 30 & 4.78 \\
\hline $\begin{array}{l}\text { Atatürk } \\
\text { P.S }\end{array}$ & 1 & 1 & 6 & - & 3 & - & - & - & - & - & 1 & - & - & - & - & - & 12 & 1.91 \\
\hline $\begin{array}{l}28 \text { Haziran } \\
\text { P.S }\end{array}$ & 1 & 1 & - & - & 3 & - & - & - & - & - & - & - & - & - & - & - & 5 & 0.80 \\
\hline $\begin{array}{l}\text { Akçakoca } \\
\text { P.S }\end{array}$ & 1 & 1 & - & 4 & 1 & - & - & - & - & - & - & - & - & - & - & - & 7 & 1.12 \\
\hline $\begin{array}{l}\text { Ulubatlı } \\
\text { Hasan P.S }\end{array}$ & 1 & 1 & 2 & - & 1 & 1 & 1 & - & - & - & - & - & - & - & - & - & 7 & 1.12 \\
\hline $\begin{array}{l}\text { Yarb. Refik } \\
\text { Cesur P.S }\end{array}$ & 1 & 2 & 5 & 5 & 5 & - & - & - & - & - & - & - & - & - & - & - & 18 & 2.87 \\
\hline $\begin{array}{l}\text { Albay } \\
\text { İbr.Kara. } \\
\text { P.S }\end{array}$ & 1 & 1 & 3 & - & 3 & - & - & - & - & - & - & - & 2 & - & - & - & 10 & 1.60 \\
\hline Kazım & & & & & & & & & & & & & & & & & 14 & \\
\hline $\begin{array}{l}\text { Karabek. } \\
\text { P.S }\end{array}$ & 1 & 2 & - & 4 & 5 & - & - & - & - & - & - & - & 2 & - & - & - & & 2.23 \\
\hline $\begin{array}{l}\text { Dr. Ferdi } \\
\text { Koçal P.S }\end{array}$ & 1 & 2 & 8 & 5 & 8 & - & - & - & - & - & - & - & 2 & - & - & - & 26 & 4.15 \\
\hline Fevzi & & & & & & & & & & & & & & & & & 11 & \\
\hline $\begin{array}{l}\text { Çakmak } \\
\text { P.S }\end{array}$ & 1 & 1 & 4 & 2 & 2 & - & - & - & - & - & - & - & 1 & - & - & - & & 1.75 \\
\hline $\begin{array}{l}\text { Mim Sinan } \\
\text { P.S }\end{array}$ & 1 & 2 & & 3 & 3 & 2 & - & - & - & - & - & - & - & - & - & - & 11 & 1.75 \\
\hline $\begin{array}{l}\text { Leyla } \\
\text { Atakan P.S }\end{array}$ & 1 & 2 & 5 & 2 & 4 & - & - & - & - & - & - & - & - & - & - & - & 14 & 2.23 \\
\hline $\begin{array}{l}\text { Tavşantep } \\
\text { e P.S }\end{array}$ & 1 & 1 & - & - & 2 & - & - & - & - & - & - & - & 5 & - & - & - & 9 & 1.44 \\
\hline $\begin{array}{l}\text { Saraybahç } \\
\text { e P.S }\end{array}$ & 1 & 2 & - & - & 2 & - & - & - & - & - & - & - & - & - & - & - & 5 & 0.80 \\
\hline $\begin{array}{l}\text { 50.Yıl } \\
\text { Cumh P.S }\end{array}$ & 1 & 1 & - & 4 & 6 & - & - & - & - & - & - & - & - & - & - & - & 12 & 1.91 \\
\hline $\begin{array}{l}\text { Bekirpaşa } \\
\text { Vakıf P.S }\end{array}$ & 1 & 2 & - & - & 3 & - & - & - & - & - & - & - & - & - & - & - & 6 & 0.96 \\
\hline $\begin{array}{l}\text { İbni Sina } \\
\text { P.S }\end{array}$ & 1 & 3 & 10 & 5 & 3 & - & - & - & - & - & 1 & - & 1 & - & - & - & 24 & 3.83 \\
\hline $\begin{array}{l}\text { Mehmetçik } \\
\text { P.S }\end{array}$ & 1 & 1 & 3 & 2 & 2 & - & - & - & - & - & - & - & 1 & - & - & - & 10 & 1.59 \\
\hline $\begin{array}{l}\text { Ulugazi } \\
\text { P.S }\end{array}$ & 1 & 3 & 10 & 4 & 10 & - & - & 1 & - & - & - & - & - & - & - & - & 29 & 4.63 \\
\hline $\begin{array}{l}\text { 75.Yıl } \\
\text { Cumh P.S }\end{array}$ & 1 & 1 & 20 & 4 & 5 & - & - & - & - & - & - & - & 2 & - & - & - & 33 & 5.26 \\
\hline $\begin{array}{l}\text { Özel } \\
\text { Atafen P.S }\end{array}$ & 2 & 5 & 50 & 50 & 70 & 2 & 2 & 1 & 6 & 1 & 2 & 1 & 10 & 3 & 1 & 1 & $\begin{array}{l}20 \\
7 \\
\end{array}$ & $\begin{array}{c}33.01^{*} \\
*\end{array}$ \\
\hline TOTAL & 30 & 50 & $\begin{array}{c}16 \\
7\end{array}$ & $\begin{array}{c}11 \\
5\end{array}$ & $\begin{array}{c}20 \\
0\end{array}$ & 6 & 4 & 2 & 6 & 1 & 6 & 1 & 34 & 3 & 1 & 1 & $\begin{array}{c}62 \\
7\end{array}$ & $\begin{array}{c}100.0 \\
0\end{array}$ \\
\hline
\end{tabular}

*Minimum, ** Maximum

As the data in Table 3 indicates, playgrounds and their components which are essential for the school gardens, where the children are expected to meet their needs for playing games, are insufficient in many of the schools. Reinforcement elements that exist in all of the studied primary schools (100\%) are "The effigy of Atatürk, flagpole and litterbins". The rate of benches and lightening elements are $60 \%$; fountains $43 \%$; arbours $16 \%$; swings $13 \%$ and slides $10 \%$. The rate of playgroups, picnic tables, seesaws, decorative pools, basketball courts, swimming pools, chessboard grounds are only $3 \%$. Maximum use rate for the reinforcement elements belong to a private school with the rate $33.01 \%$ whereas minimum rate is $0.64 \%$.

Table 4 indicates the reinforcement element status of high schools and their equivalents. According to the presented data, reinforcement elements that exist in all of the studied high schools and their equivalents (100\%) are "The effigy of Atatürk and flagpole". The rate of benches is $84 \%$; lightening elements $79 \%$; litterbins $74 \%$; basketball courts 47\%; basketball and volleyball court 47\%; fountains $42 \%$; football field 37\%; volleyball court 32\%; arbour and containers 26\%; picnic tables $21 \%$; playpen, swimming pool and bicycle lot $5 \%$. Maximum use rate for the reinforcement 
elements in high schools and their equivalents is $24.94 \%$ whereas minimum use rate is $0.47 \%$.

Table 4. Reinforcement element diversity and use rates in high schools and their equivalents

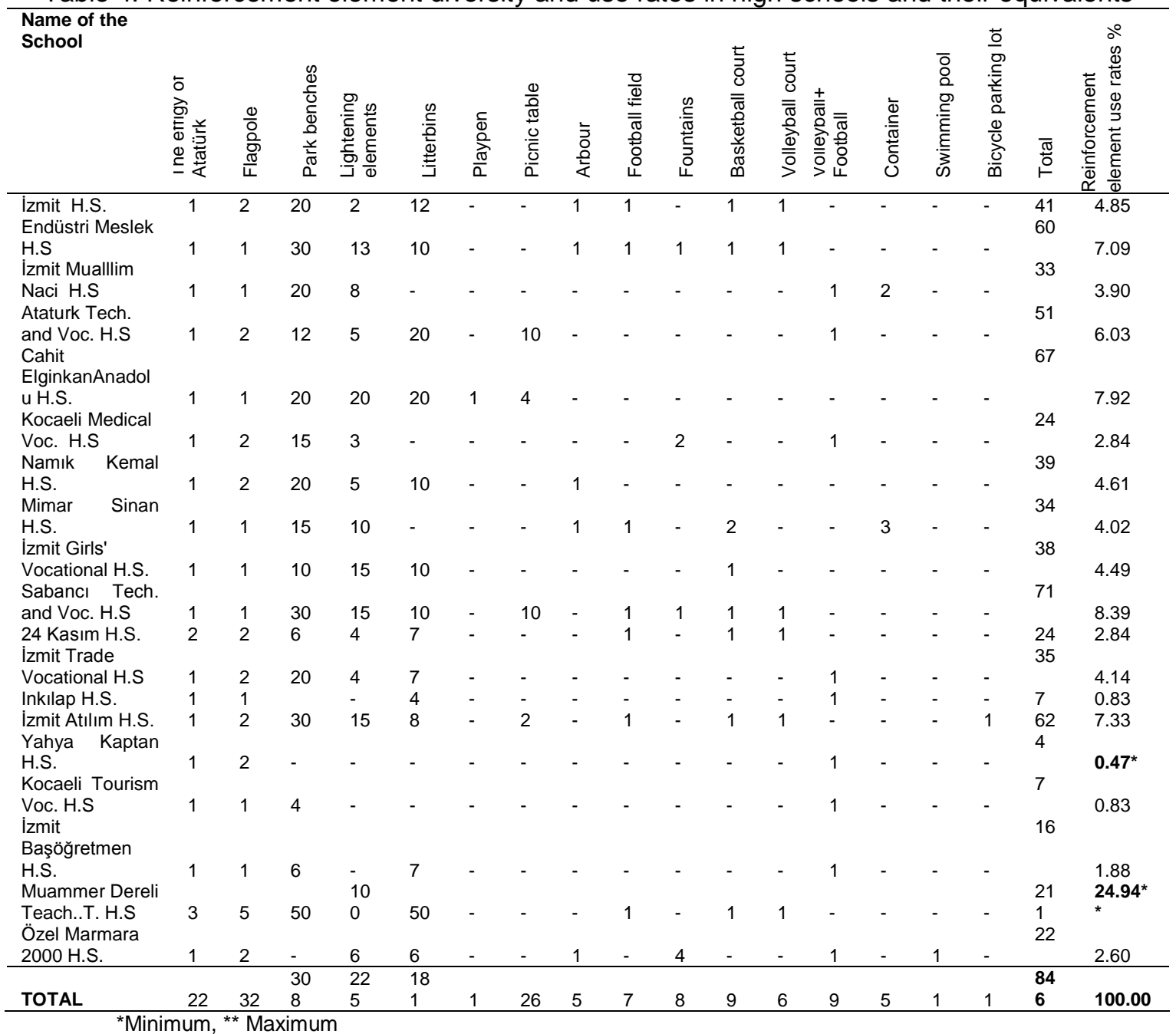

\subsection{Findings related to vegetal components}

Another essential landscape design component in school gardens is vegetation. Plants make important and miscellaneous contribution in creation of outdoor green spaces. Especially in primary school gardens, plants, which are important living components, form a kind of integrity with the playgrounds and provide students different game opportunities, enhance their creativity and enable them to be in touch with the nature (Acar, 1997; Acar, 2003). According to the studies carried on children behaviours, the children who have the opportunity of playing in school gardens that bear more natural characteristics and high landscaping features, become more creative and their learning perceptions are more effective (Özdemir and Yılmaz, 2009). Table 5 shows the plant species used in the gardens of the primary schools examined within the scope of the study. 
Table 5. Plant species used in primary school gardens and their rate of use

\begin{tabular}{|c|c|c|c|}
\hline \multirow{2}{*}{\multicolumn{2}{|c|}{ Plant species used }} & \multicolumn{2}{|c|}{ Species } \\
\hline & & Number & $\%$ \\
\hline Tree species & $\begin{array}{l}\text { Abies spp Acacia spp., Cedrus atlantica, Cupressus } \\
\text { spp, Juniperus spp Juglans regia Pinus pinea Pinus } \\
\text { nigra Platanus orientalis Populus spp Prunus avium } \\
\text { Quercus spp Tilia cordata }\end{array}$ & 13 & 52 \\
\hline $\begin{array}{l}\text { Small tree } \\
\text { species }\end{array}$ & $\begin{array}{l}\text { Malus floribunda Eriopteria japonica Ficus carica, Morus } \\
\text { alba Prunus laurocerasus Punica granatum Pyrus spp. } \\
\text { Salix caprea }\end{array}$ & 8 & 32 \\
\hline Shrub species & $\begin{array}{l}\text { Nerium oleander Rosa spp. Rosa canina, } \\
\text { Chaneomeles japonica }\end{array}$ & 4 & 16 \\
\hline $\begin{array}{l}\text { Groundcover } \\
\text { plants (creeping } \\
\text { plants) }\end{array}$ & - & - & - \\
\hline Grass plant & - & - & - \\
\hline Total & & 25 & 100 \\
\hline
\end{tabular}

Table 5 indicates that plant diversity in school gardens are low. Most commonly used plant species seems to be trees when all primary schools considered (52\%). Among the trees, especially tall trees are preferred. It has been understood that shrubs are used slightly with a rate of $16 \%$. On the other hand, groundcover plants are not preferred. Most commonly preferred races are as follows: Apocynaceae, Cupressaceae,Fabaceae, Juglandaceae, Lythraceae, Moraceae, Pinaceae, Platanaceae, Rosaceae, Salicaceae and Tiliaceae.

When compared with primary school gardens, the gardens of high schools and their equivalents are richer in vegetation diversity (Table 6). It has been observed that tree species, especially tall ones, are commonly preferred (54.84) when all high schools and their equivalents considered. Use rate of shrubs is $33.87 \%$ whereas use of groundcover plants is less (3.23). Adoxaceae, Amaryllidaceae. Apocynaceae, Araliaceae, Arecaceae, Berberidaceae, Betulaceae, Buxaceae, Caprifoliaceae, Celastraceae, Cupressaceae, Fabaceae, Garryaceae, Hydrangeaceae, Lamiaceae, Lauraceae, Magnoliaceae, Malvaceae, Oleaceae, Paulowniaceae, Pinaceae, Pittosporaceae, Platanaceae, Poaceae, Rosaceae, Salicaceae, Sapindaceae, Simaroubaceae, Tamaricaceae, Tiliaceae. It has also been observed that herbaceous plant use is insufficient. Commonly preferred herbaceous plants are Tagetes erecta , Salvia splandens, Viola odorata, Petunia hybrida, Celosia argentea.

Table 6. Plant species used in the gardens of high schools and their equivalents and their rate

\begin{tabular}{|c|c|c|c|}
\hline \multicolumn{2}{|r|}{ Plant species used } & \multicolumn{2}{|c|}{ Species } \\
\hline & & Number & $\%$ \\
\hline Tree species & $\begin{array}{l}\text { Ailanthus altissima, Abies nordmannianna, Acacia spp., Acer negundo, } \\
\text { Aesculus hippocastanum, Betula pendula, Cedrus deodora, Cedrus } \\
\text { libani, Cupressusparis leylandii, Cupressus sempervirens, } \\
\text { Chamaecyparis lawsoniana, Fraxinus excelsior, Juniperus orientalis, } \\
\text { Juniperus communis, Magnolia grandiflora, Pavlonia tomentosa, Picea } \\
\text { excelsa, Picea oriantalis, Picea pungens, Pinus nigra, Pinus slyvestris, } \\
\text { Pinus pinea, Pinus brutia, Platanus orientalis, Populus alba, Photinia } \\
\text { fraseri, Quercus spp., Robinia pseudoacacia "Umbraculifera", Salix } \\
\text { babylonica, Thuja occidentalis, Thuja orientalis, Tilia tomentosa, } \\
\text { Washingtonia robusta, Washingtonia filifera }\end{array}$ & 34 & 54.84 \\
\hline
\end{tabular}




\begin{tabular}{|c|c|c|c|}
\hline $\begin{array}{l}\text { Small tree } \\
\text { species }\end{array}$ & $\begin{array}{l}\text { Acer palmatum, Lagerstroemia indica, Olea eureopeaea, Prunus } \\
\text { cerasifera pissardi nigra, Tamarix tetrandra }\end{array}$ & 5 & 8.06 \\
\hline $\begin{array}{l}\text { Shrub } \\
\text { species }\end{array}$ & $\begin{array}{l}\text { Abelia floribunda, Agave americana, Aucuba japonica, Berberis } \\
\text { thunbergii "Atropurpurea", Berberis thunbergii, Buxus sempervirens, } \\
\text { Cassia spp., Cortaderia selloana, Eonymus japonicum, Hibiscus } \\
\text { syriacus, Hydrangea hortensis, Laurus nobilis, Ligustrum vulgare, } \\
\text { Nerium oleander, Prunus laurocerasus, Pitosporrum tobira, Pyracantha } \\
\text { cocinea, Rosa spp., Rosmarinus officinalis, Spirea vanhoutteii, } \\
\text { Viburnum opulus }\end{array}$ & 21 & 33.87 \\
\hline $\begin{array}{l}\text { Groundcover } \\
\text { plants } \\
\text { (creeping } \\
\text { plants) }\end{array}$ & Hedera helix, Juniperus horizontalis & 2 & 3.23 \\
\hline Grass plant & - & - & - \\
\hline Total & & 62 & 100 \\
\hline
\end{tabular}

On the other hand, it has been observed that school gardens of both primary schools and high schools and their equivalents are designed to be used for parking, walking and for official ceremonies. Therefore, use of hard soil in outdoor spaces is widespread and most commonly preferred construction material for mentioned hard soil is asphalt. Besides, use of school gardens by the students during holiday periods prohibited. In schools that have green spaces, plants are generally cared by school staff such as the retainers or furnace stokers due to limited financial source and labour force which prevents the plants be cared regularly and consciously.

\section{DISCUSSION and CONCLUSIONS}

School gardens are education centred spaces that enable students to learn about plants, wildlife and their relation and enrich the schools visually in addition to vitalising school buildings. Well- designed school gardens include lots of important educational materials and they give chance to various teaching strategies. Besides their positive effects on education, school gardens make serious contribution to urban ecology, urban green space organisation, urban aesthetic etc. In order to be able to fulfil their mentioned functions, school gardens should be implemented with landscape design and maintenance of the design should be guaranteed. In a good design, live components (plants) and non-living components (reinforcing elements, floor elements etc.) should be applied in accordance with a design created considering some principles.

In this study, current space use (including outdoor green spaces and indoor spaces) of 49 schools located in İzmit, central district of Kocaeli Province; current diversity statuses of reinforcing elements and vegetal components have been specified and their landscape design has been evaluated.

It has been ascertained that the majority of the indoor spaces of the primary schools, high schools and their equivalents located in Izmit consist of the school building and no other indoor space for sports activities, recreation, research and social activities exist. It has also been concluded that the amount of parade grounds, recreational areas, parking lots, playgrounds and sports courts, outdoor classrooms and areas for performance are either insufficient or do not exist. In the majority of the school gardens concrete hard floors designed as parade grounds are also used as areas for students to meet play and sport's needs. However, according to the principles regarding the designing of the school gardens by The Ministry of National Education 
besides educational structures and students' hostels at boarding schools, schools should have amphitheatres and suitable areas for outdoor classes, at least one volleyball court and one basketball court, indoor sports hall and a miniature football pitch, playgrounds for traditional children games, walking paths and parade areas providing a space of at least $2 \mathrm{~m}^{2}$ for each student (http://www.meb.gov.tr)

Akdoğan,(1972) states that the standards for school gardens offer a minimum amount of $25 \mathrm{~m}^{2}$ space per student and this standard is considered in many countries. Among the schools studied, only one primary school is in accordance with this standard with $39.22 \mathrm{~m}^{2}$ space per person. In this case, only $3.3 \%$ of primary schools in Izmit is applicable to this standard. As for high schools and their equivalents, $21.05 \%$ of the schools are in accordance with the standard and maximum rate is $57.01 \mathrm{~m}^{2} /$ person.

The Ministry state that school gardens should also include as much as possible green areas; ecologically compatible plants; flower parterres which are designed around some principles and are easy to maintain. (http://www.meb.gov.tr) Thus, the cold and monotonous effect of hard floors should be broken yet the schools located in Izmit are insufficient in terms of open-green space per student. Only $43.33 \%$ of the primary schools and $57.89 \%$ of the high schools and their equivalents involved in the study have green spaces. The rest of the schools do not have green spaces when their outdoor spaces considered. Hence, in his study concerning the effects of playgrounds utilised in school gardens on children, Young (1997) emphasises that those playgrounds to be utilised in school gardens should be composed of encouraging elements besides evoking curiosity in children. On the other hand, in his study on transforming school gardens into learning environments, Takahashi (1999) states the school gardens to have great potential in terms of learning. Indeed, Aksu and Demirel (2011), state that due to intense urbanisation, outdoor playgrounds of children are gradually disappearing and existing or recently constructed playgrounds are insufficient. They also emphasize that children are growing being deprived of gaming activities which is essential for healthy development of them. Therefore, they state, one of the most important function of school gardens is meeting this gaming need of the children. Wagner (2000) states that schools having sufficient green space, are able to form more flexible learning environments. Bell et al. (2006) emphasises that school gardens which are rich in green spaces enhance the quality of physical activities. In addition, Subramaniam, (2002) states that students attending the schools having sufficient green space have greater enthusiasm and interest in learning.

The Ministry also states that every school garden necessarily has a space for Ataturk's Bust and flag posts, design components such as appropriate game tools and equipment for the age groups, arbours, sitting areas and sitting groups. (http://www.meb.gov.tr) Only 6.66\% of the primary schools in İzmit have playgroups; $13.33 \%$ have swings and $10 \%$ have slides. On the other hand, none of the primary schools have basketball courts or swimming pools. As for high schools and their equivalents, $42 \%$ have basketball courts; $31.5 \%$ have volleyball courts; $47 \%$ have multipurpose fields suitable for both basketball and volleyball; $5 \%$ have swimming pools. Moreover, it has been ascertained that most of the school gardens are covered with hard materials (concrete-asphalt-paving stone etc.), plants have been rarely used and vegetation cover almost does not exist. Commonly an unsuccessful planting is carried out with seasonal flowers around the effigy of Atatürk and often, landscaping of the effigy is deemed to be fulfilled. Unfortunately neither shrubs nor groundcover plants are involved sufficiently. These findings are similar to previous studies. In his study Özdemir (2011) carried out in Bartın Province states that primary school gardens are insufficient in terms of structure, landscape design, reinforcement components and green spaces. Although the borders of the gardens are vegetated, they are formed as concrete, asphalt or dusty-muddy spaces. Özdemir also states that the gardens are 
used as car parks during spare times. Similarly Pickard (2002), argues that while planning school gardens, areas for team games, playfields with firm ground, informal social spaces and habitat areas should be regarded. Karakaya and Kiper (2013), state that the gardens of most of the primary schools in Tekirdağ are covered with concrete and asphalt and have poor layouts in terms of plants and reinforcement components. In a study concerning the restoration of a Primary School Graden located in Canada Penner (2000), states that designing school gardens as healthier, liveable, positive environments with modern educational and recreational opportunities through natural outdoor space layouts is necessary to enhance the life quality of children.

Çelik (2012) emphasises that the gardens of pre-school educations institutions in Kocaeli are not used effectively and during environmental planning, outdoor space planning is ignored. On the other hand Erdönmez (2007) states that the experience and information obtained through the games inside the school gardens during the break times by the child are as important as the other information gained through other educational means and school itself. In their study concerning the contribution of school gardens to education in Canada, Collyer et al. (2001) state that various kinds of trees, shrubs and natural plants were planted in 6 school gardens upon the requests by the educators, students and people. Moreover, these mentioned gardens were provided with grass areas, decorative pools and vegetable gardens and they were furnished with several statues. Thus, they state, subjects included in the curriculum were put into practice and the students were able to play in a healthier and safer environment. Corson (2003), emphasises that learning is not limited to the indoor spaces at school. Outdoor spaces have great potential as learning environments. Great numbers of new-built schools in America have been designed with this awareness including amphitheatres, outdoor areas dedicated to musical and painting activities, gardens, weather stations. Different topographical features and vegetation have also been considered during this mentioned design process.

There are great differences between the schools located in Izmit in terms of open space and green space existence so much so that it has been specified that the difference between the school with the largest open space and the school with the least open space is 74 times higher in primary schools and 27 times higher in high schools and their equivalents. Similarly, the difference when green space considered has been specified to be 313 times higher in primary school while it is 57 times higher in high schools and their equivalents. It is not possible to mention about a balanced practise in terms of reinforcement component and plant use when there is not a standard in the amount of open space per person.

Consequently, it is obvious that the school gardens in Izmit do not have either appropriate space use, components or plant use that provide students with game activities. All the school gardens, without any exception, should be regarded as a part of education and training; a uniform standard should be adopted in the organisation of spaces and components in order to ensure that all students have equal access to education and training opportunities; the space organization in school gardens should be designed to address various age groups and green spaces and attractive vegetative design that offer students the opportunity to relax and to deepen the understanding of the ecological system should be employed. 


\section{REFERENCES}

Acar, Cengiz, Trabzon ve Yöresinde Yetişen Doğal Bazı Yerörtücü Bitkilerin Peyzaj Mimarlığında Değerlendirilmeleri Üzerine Bir Araştırma, Doktora Tezi, K.T.Ü., Fen Bilimleri Enstitüsü, 1997, Trabzon.

Acar, Habibe, Çocuk Oyun Alanlarında Kullanıcıların Bitki Tercihlerinin Belirlenmesi Üzerine Bir Araştırma: Trabzon Kenti Örneği, Yüksek Lisans Tezi, K.T.Ü., Fen Bilimleri Enstitüsü, 2003, Trabzon.

Akdoğan, Günel, Beş Büyük Şehirde Çocuk Oyun Alanları, Okul Bahçeleri ve Spor Alanlarının Yeterlilikleri ve Planlama Prensipleri Üzerinde Bir Araştırma, A.Ü.Ziraat Fakültesi Yayınları: 522, Sayfa Sayısı 84, 1972. Ankara.

Aksu, Özge Volkan, Demirel, Öner, Trabzon Kenti ilköğretim okul bahçelerinde tasarım ve alan kullanımları. SDÜ Orman Fakültesi Dergisi, 12: 40-46, 2011.

Bell, Anne C., Dyment, Janet E, Grounds for Action. Promoting Physical Activity Through School Ground Greening in Canada. Evergreen, Canada, 61p. 2006.

Bradley, Lucy Kennedy, Tierra Buena, TheCreation of Urban Wildlife Habitat in An Elementary School in The Inner City. Children'sEnvironments, Volume 12, Issue 2, p. 102-110, U.S.A. 1995.

Brand 1997-2001; Plant Uconn database of trees, shrubs and vines. http://www.hort.uconn.edu (Date of Access: 21.09. 2016)

Collyer Cam, Irvine Steve, Grounds For Learning. Stories and Insights From Six Canadian School Ground Naturalization Initiatives. Canada, 32s. 2001.

Corson, Cheryl, Grounds for Learning: Hope for America's Derelict Schoolyards. Learning by Design. 2003. http://www.cherylcorson.com/pdfs/groundsforlearning.pdf (Date of Access: 15.09. 2016)

Çelik, Aysun, Okul öncesi Eğitim kurumlarında açık alan kullanımı: Kocaeli Örneği. Atatürk Üniv. Ziraat Fak. Dergisi. 43(1):79-88. 2012.

Çorlu, Ş. 1996. İstanbul Kenti Örnek Okul Bahçelerinin Peyzaj Mimarlığı Açısından İrdelenmesi. İ.Ü.FBE Orman Fakültesi Peyzaj Mimarlığı Anabilim Dalı. Yüksek Lisans Tezi. İstanbul.

Davis, Peter Hadland, 1965-1988; Flora of Turkey and the east aegean islands. Edinburgh University Press. Volume 1-10. Edinburgh.

Erdönmez, İ. M. Ö. 2007. İlköğretim Okul Bahçelerinde Peyzaj Tasarım Normları, İstanbul Orman Fakültesi Dergisi, 1, B, (57), Sayfa 108-120.

Fjortoft, Ingunn and Jostein, Sageie, The Natural Environment As A Playground For Children: Landscape Description and Analysis of a Natural Landscape. Landscape and Urban Planning,48(1/2) 83-97. 2000.

Golby Michael, Appleby Rosemary, New School-New Era, Westminster Studies in Education, Vol.20, Page 65. 1997. 
Evaluations on The Landscapes of School Gardens: İmit Central District of Kocaeli Province Sample

Karakaya Beste, Kiper Tuğba, Edirne Kent Merkezindeki Bazı İlköğretim Okul Bahçelerinin Peyzaj Tasarım İlkeleri Açısından Mevcut Durumunun Belirlenmesi. Tekirdağ Üniversitesi Ziraat Fakültesi Dergisi 10 (1): 59-71, 2013.

Krussmann Gerd, 1984-1986; Manual of cultivated broad-leaved trees and shrubs. Timber Press. Portland Oregon. 678 p.

Mamıkoğlu Necati Güvenç, Trees and shrubs in Turkey, NTV Publications. Istanbul, ISBN: 978-875-6690-80-3. 728 p. 2007.

Mataracı, Tuncay, Marmara region natural exotic wood trees and shrubs, Tema Publications ISBN: 971716937-4. 371 p. 2002.

Özdemir, Aydın, Yılmaz, Oğuz, 2009. İlköğretim Okulları Bahçelerinin Çocuk Gelişimi ve Sağlıklı Yaşam Üzerine Etkilerinin İncelenmesi ,Üç Aylık Eğitim ve Sosyal Bilimler Dergisi, Sayı 181, S, 94-108.

Özdemir Aydın, Çorakçı Mehmet, Participation in the greening of schoolyards in the Ankara public school system. Scientific Research and Essays 5(15): 2065-2077. 2010.

Özdemir, Ayşe, Okul bahçesi peyzaj tasarım anlayışındaki değişim ve bu değişimin uygulamaya yansımalarının Bartın kenti örneğinde irdelenmesi. Bartın Orman Fakültesi Dergisi. 13(19):41-51, 2011.

Pamay, Besalet, Plant Material I: Trees and shrubs. Uycan Press. Istanbul. 80p, 1992.

Pamay, Besalet, Plant Material II: Woody origins, flowering shrubs, vines, cacti and succulent plants, reeds. Orhan Press. Istanbul.128 p, 1993.

Penner, Tracy, Grandview U'uqinak'uuh Community School Yard. City Farmer, Canada's Office of Urban Agriculture. Canada. 2000.

Pickard, Quentin, The Architects' Handbook. Blackwell Science, UK, 468p, 2002.

Subramaniam, Aarti, Garden-Based Learning in Basic Education: A Historical Review. Center for Youth Development. University of Califronia. Davis, California, USA, 12p, 2002.

Takahashi, Nancy, Developing School Grounds As Learning Places. University of Virginia, Thomas Jefferson Center For Educational Design. Charlottesville, Cilt No: 3, p. 27-57-58. 1999.

Wagner, Cheryl, Planning School Grounds for Outdoor Learning. National Clearinghouse for Educational Facilities. 6p, 2000.

Wolf, O, Schulgelaendeund Schulgrün-Gartenund Landschaft, Juli, p ,224-226, 1967.

Yaltırık, Faik, Dendrology II, Angiospermae, İstanbul University. Publication number: 3509. 256 p, 1988.

Young, Susan D, Children's Behaviours In A School Play Environment: A Case Study At Victoria Public School. The University of Guelph. MSc Thesis, Canada, 102p, 1997.

http://www.meb.gov.tr (Date of Access: 04.03.2017) 